\title{
THE ADEQUACY OF EXISTING SUPPORT SYSTEMS IN ADDRESSING THE ISSUE OF TEENAGE PREGNANCIES IN MALAYSIA: A LEGAL RESPONSE
}

\author{
Aishah Mohd Nor ${ }^{*}$ \\ Najibah Mohd Zin ${ }^{* *}$ \\ Roslina Che Soh ${ }^{* * *}$
}

\begin{abstract}
This article examines the adequacy of the current support systems in addressing the issue of teenage pregnancies in Malaysia. This study was conducted primarily through a doctrinal study of existing literature such as articles, journals and reports related to the current issues encountered by the pregnant teenagers. There is also a non-doctrinal method carried out whereby the researchers had conducted fieldwork interviews with the government department, non-government organisations (NGOs) and social activist on the efforts done in addressing the problem. Due to the lack of a specific policy on teenage pregnancies in Malaysia, there have been concerns on issues related to the rights of these teenagers to education during pregnancy; criminal issues on abortion, infanticide and child sexual grooming; child marriages and the lack of support from parents, family members and the society for care, motivation, healthcare and preparation for motherhood among these teenagers. The findings establish the current support system is inadequate to meet the contemporary needs of pregnant teenagers. It is suggested that a comprehensive legal framework for teenage pregnancies in Malaysia needs to be put in place.
\end{abstract}

Syariah Officer, Syariah Judiciary Department Malaysia. Currently a PhD student at the Department of Islamic Law, AIKOL, International Islamic University Malaysia, Kuala Lumpur, Malaysia. E-mail: aishahmn2907@gmail.com.my

** Professor, Department of Islamic Law, AIKOL, International Islamic University Malaysia, Kuala Lumpur, Malaysia

*** Associate Professor, Department of Islamic Law, AIKOL, International Islamic University Malaysia, Kuala Lumpur, Malaysia

[Received: 28 November 2018, Accepted: 10 December 2018, Published: 30 December 2018] 
These can include legislating necessary laws and policies, which can be more effective through integrated services and proper monitoring and enforcement in order to meet the current needs of the targeted group.

Keywords: adequacy, support systems, teenage pregnancy, service deliveries, Malaysia

\title{
KETEPATAN SISTEM SOKONGAN SEDIA ADA DALAM MENANGANI PERMASALAHAN KEHAMILAN REMAJA DI MALAYSIA: SUATU TINDAK BALAS PERUNDANGAN
}

\begin{abstract}
ABSTRAK
Kajian ini menganalisa ketepatan sistem sokongan yang sedia ada dalam menangani isu yang berkaitan dengan kehamilan remaja di Malaysia. Kajian ini adalah kajian penyelidikan undang-undang secara doktrinal keatas literatur sedia ada seperti makalahmakalah, jurnal-jurnal serta laporan yang berkaitan tentang kehamilan remaja. Kajian turut menggunakan kaedah nondoktrinal di mana para pengkaji telah menemuramah pegawai dari jabatan kerajaan, NGO serta aktivis sosial yang berkaitan dengan usaha dan pendekatan yang telah dilakukan dalam menangani isu ini. Ketiadaan polisi khusus untuk remaja hamil di Malaysia menimbulkan kebimbangan terhadap hak mereka seperti hak untuk mendapat pendidikan semasa kehamilan; halhal jenayah seperti pengguguran janin, pembuangan bayi dan pengantunan kanak-kanak; perkahwinan kanak-kanak dan kekurangan sokongan daripada ibu bapa, keluarga dan masyarakat untuk perhatian dan bimbingan, perkhidmatan kesihatan dan persediaan keibubapaan. Hasil kajian mendapati terdapatnya ketidakcukupan pelaksanaan sistem sedia ada dalam memenuhi keperluan semasa golongan remaja hamil. Dicadangkan agar satu kerangka undang-undang untuk remaja hamil di Malaysia dapat diwujudkan agar undang-undang dan polisi menjadi lebih efektif melalui penyampaian perkhidmatan berintegrasi dan pemantauan penyampaian yang baik bagi memenuhi keperluan semasa kumpulan sasaran.
\end{abstract}

Kata Kunci: ketepatan, sistem sokongan, kehamilan remaja, penyampaian perkhidmatan, Malaysia 


\section{INTRODUCTION}

Pregnancies among teenagers have become a common issue in today's global society. In Malaysia, the numbers of teenage pregnancies are increasing. Statistics from the Department of National Registration of Malaysia show that in 2017 there were 4,992 illegitimate children born to teenage mothers aged eighteen and below and until June 2018, as many as 1,664 illegitimate children were born. ${ }^{1}$ These figures, however, only represent the registered live births of pregnant teenagers, which exclude abortions, stillbirths and baby dumping cases. Thus, existing data is not able to capture the exact number and it may actually underestimate the seriousness of teenage pregnancies in the country.

A teenage pregnancy is defined as pregnancy occurring among teenagers aged nineteen years or younger. ${ }^{2}$ It is perceived to be a problem in Malaysia when the pregnancy happens out of wedlock. An out of wedlock pregnancy is considered to be against the social norms and brings shame and disgrace to the family. ${ }^{3}$ The unmarried mother is perceived as being an immoral and an ill-mannered person, ${ }^{4}$ sinful and unacceptable. ${ }^{5}$ Pregnancies among teenagers lead to various negative consequences. Among them are these teenagers who usually become

\footnotetext{
${ }^{1}$ Natasha Joibi, "5,000 Babies Born to under 18s", The Star 23 July, 2018, https://www.thestar.com.my/news/nation/2018/07/23/5000-babies-born-tounder18s-incest-and-child-abuse-among-factors-behind-such-cases-says-wanazizah (accessed 26 July, 2018).

${ }^{2}$ UNICEF Malaysia Communications, Young People and Family Planning: Teenage Pregnancy, (Malaysia: UNICEF Malaysia Communications, 2008).

${ }^{3}$ Nor Jana Saim, "Social Support, Coping, Resilience and Mental Health in Malaysian Unwed Young Pregnant Women and Young Mothers: Their Experiences While Living in a Shelter Home," (Ph.D. thesis, Umea University, Sweden, 2013).

${ }^{4}$ Jay G Silverman, Anita Raj, Lorelei A Mucci and Jeanne E Hathaway, "Dating Violence against Adolescent Girls and Associated Substance Use, Unhealthy Weight Control, Sexual Risk Behavior, Pregnancy, and Suicidality”, Jama 286, no. 5 (2001).

5 Beng Beng Ong and Michael Green, "Infanticide in Malaysia: Two Case Reports and a Review of Literature", The American Journal of Forensic Medicine and Pathology 24, no. 1 (2003). This is especially true among Muslims due to the prohibition of sexual intercourse out of wedlock under Islamic law.
} 
school dropouts, commit abortion, infanticide become victims of child marriages and child sexual grooming. The lack of a support system to help them through the process of pregnancy, labour and motherhood at a very young age exacerbate matters, not only for themselves, but also for the born child. ${ }^{6}$

\section{LITERATURE REVIEW}

In 1995, Malaysia has ratified, albeit with reservations, the international treaties relating to the rights of children and women, namely the United Nation Convention on the Rights of Children (UNCRC) and the Convention on the Elimination of All Forms of Discriminations Against Women (CEDAW). Malaysia has subsequently taken progressive steps in reforming the national laws and established institutional framework in its efforts to uphold the rights under the conventions within the suitability of the Malaysian law and society. ${ }^{7}$ Although the conventions highlight the rights and protection of children and women, nevertheless, it indirectly addresses the rights of teenage girls as being minors and young women at the same time. Malaysia has no specific policy on teenage pregnancies. Therefore, the framework for children, in general, would include teenagers aged eighteen years old and below, as it falls within the same category.

The issue of teenage pregnancy has been addressed in various areas. One of them is the right to education during pregnancy. The right to education has been accepted as a universal norm as can be seen clearly under the Universal Declaration of Human Rights and other human rights treaties. ${ }^{8}$ Nearly all the countries in the world have pledged to uphold the

\footnotetext{
${ }^{6}$ Nor Jana Saim, "Social Support, Coping, Resilience and Mental Health in Malaysian Unwed Young Pregnant Women and Young Mothers: Their Experiences While Living in a Shelter Home," (Ph.D. thesis, Umea University, Sweden, 2013).

7 Rojanah Kahar, "A Study on Policies and Laws Affecting Children in Malaysia: An Appraisal of the Children's Best Interests," (Ph.D. thesis, International Islamic University Malaysia, 2010).

8 Rojanah Kahar, "A Study on Policies and Laws Affecting Children in Malaysia: An Appraisal of the Children's Best Interests," (Ph.D. thesis, International Islamic University Malaysia, 2010), 234.
} 
right to education under Article 28 and 29 of UNCRC, also Article 10 of CEDAW. In Malaysia, Article 12 of the Federal Constitution provides the right to education is a right for all Malaysian citizens, and thus there can be no discrimination and this includes pregnant teenagers. However, in reality, it has become a common practice for pregnant students to drop out of school to hide their pregnancies due to the negative perception of the society towards them. ${ }^{9}$ This clearly disturbs their education and often results in them getting a poor education and this further leads to the lack of qualifications. This in turn affects their occupational chances and financial abilities in the future. ${ }^{10}$

More seriously, unwanted pregnancies normally lead to abortion and infanticide (baby dumping), which are illegal under the Penal Code. ${ }^{11}$ Abortion is a highly sensitive issue in Malaysia associated with social, religious and cultural values. ${ }^{12}$ The reluctance to address the concerns on abortion makes it difficult for women to make informed decisions on this matter. The restrictive grounds of abortion lead to illegal operations of abortions, which is normally dangerous as it is performed below the minimum standard of safe operation. ${ }^{13}$ Nevertheless, in despair to hide from the humiliation of public shaming for being pregnant out of wedlock, these teenagers would choose these life-threatening procedures of unsafe or self-induced abortions, rather than facing the stigma of being ostracised by their family, peers and the society in general. ${ }^{14}$

${ }^{9}$ S M Shahidul and A H M Zehadul Karim, "Factors Contributing to School Dropout among the Girls: A Review of Literature," European Journal of Research and Reflection in Educational Sciences 3, no. 2 (2015).

${ }^{10}$ Kul Bhushan Suri, "The Problem of Teenage Pregnancy: An Educational Imperative," Journal of Multicultural Social Work 3, no. 3 (1994).

${ }^{11}$ S 312-314, s 309A.

${ }^{12} \mathrm{R}$ Abdullah and Y L Wong, "Access to Abortion Services in Malaysia: A Right-Based Approach," Abortion in Asia: Local Dilemmas, Global Politics. (New York: Berghahn Books, 2010).

${ }^{13}$ Wah Yun Low, Wen Ting Tong, Yut Lin Wong, Ravindran Jegasothy and Sim Poey Choong, "Access to Safe Legal Abortion in Malaysia: Women's Insights and Health Sector Response", Asia-Pacific Journal of Public Health / Asia-Pacific Academic Consortium for Public Health 27, no. 1 (2015).

${ }^{14}$ Wah Yun Low, Wen Ting Tong, Yut Lin Wong, Ravindran Jegasothy and Sim Poey Choong, “Access to Safe Legal Abortion in Malaysia: Women's 
Aside from abortion, infanticide is also found to be committed mostly by teenagers or women who gave birth before marriage. This happens as a result of being ill-equipped to deal with unwanted pregnancies and the fear of what the community might say. ${ }^{15}$ Malaysia is fighting against infanticide and has taken measurable efforts in preventing it. Aside from penalising the offenders, another alternative intervention is the baby hatch program, aiming to protect the innocent babies by placing them in a safer place. ${ }^{16}$

Another worrisome tendency is the possibility that teenage pregnancy is an indicator of sexual offences committed towards minors. This usually involves a paedophile, who befriends and establishes an emotional connection with the child with the intention to sexually abuse her. This can happen over the internet ${ }^{17}$ or sometimes within the family or someone close to the child like the teachers, caretakers and neighbours. ${ }^{18}$ Perpetrators of child sexual abuse can come from all walks of life and from diverse social backgrounds. Child victims of sexual abuse are not a homogeneous group. A study ${ }^{19}$ found that children who experience family problems, arguments at home and abuse or violence are more vulnerable to sexual grooming and exploitation. Children who run away from home, those who play truant from school or are involved

Insights and Health Sector Response", Asia-Pacific Journal of Public Health / Asia-Pacific Academic Consortium for Public Health 27, no. 1 (2015).

${ }^{15}$ Norhasmah Mohd Zain, "Outcomes of Pregnancy among Unmarried Mothers in Malaysia," (PhD thesis, Universiti of Malaya, 2016).

${ }^{16}$ Mazbah Termizi, Noor Ismawati Mohd Jaafar, Nurhidayah Abdullah, Mariam Saidona Tagaranao and Yasmin Hanani Mohd Safian, "Comparative Study on Punishment and Preventive Methods of Baby Dumping: Malaysian Perspectives", International Journal of Technical Research and Application 2, no. 4 (2014).

${ }^{17}$ R.AGE, "Why We Need Anti-Grooming Laws," June 14, 2016, accessed January 31, 2017, http://rage.com.my/we-need-grooming-laws/.

${ }^{18}$ Lee Lam Thye, "Malaysia Must Enact Anti-Grooming Law," New Straits Times, June 17, 2016, accessed January 31, 2017, http://www.nst.com.my/news/2016/06/152505/malaysia-must-enact-antigrooming-law.

${ }^{19}$ Elaine Chase and June Statham, The Commercial Sexual Exploitation of Children and Young People: An Overview of Key Literature and Data, (London: University of London, Institute of Education, Thomas Coram Research Unit, 2004). 
in substance abuse are all vulnerable to being targeted by persons who wish to exploit them sexually. ${ }^{20}$

This leads the discussion to the issue of child marriages, which are marriages where one or both parties are below 18 years old. Although there is no specific minimum age for marriage under CEDAW or UNCRC, both treaties recommended that the minimum age for marriage for both boys and girls should be no lower than 18 years. ${ }^{21}$ UNCRC requires the states to abolish child marriages, ${ }^{22}$ which was considered a traditional practice prejudicial to the health of children. ${ }^{23} \mathrm{CEDAW}$ provides that the marriage of a child under eighteen years old shall have no legal effect. ${ }^{24}$ However, despite Malaysia's agreement to ratify the conventions, no amendment has been done. Hence, child marriages are still legal in Malaysia, where the minimum age for girls is 16 years old for non-Muslims ${ }^{25}$ and below sixteen years old for Muslims. ${ }^{26}$ Often child marriages are resorted as a way to "solve" the problem of teenage pregnancies in Malaysia.

The transition from pregnancy to motherhood and adjustments to new patterns, responsibilities and routines are not easy. Coping with these changes requires teenage mothers to rely on the support of their next of kin and also some non-kin social networks. ${ }^{27}$ Researchers found

${ }^{20}$ Elaine Chase and June Statham, The Commercial Sexual Exploitation of Children and Young People: An Overview of Key Literature and Data, (London: University of London, Institute of Education, Thomas Coram Research Unit, 2004).

${ }^{21}$ CEDAW Committee, General Recommendation No. 21, 1994, A/47/38 in UNICEF East Asia and Pacific Regional Office, "Legal Protection From Violence: Analysis of Domestic Laws Related to Violence Against Children in ASEAN Member States," UNICEF EAPRO, (Bangkok, 2015).

${ }^{22}$ General Comment CRC Committee, No.13.

${ }^{23}$ UNCRC 1989, Art 24(3).

${ }^{24}$ CEDAW, Art 16(2) and its interpretation in General Recommendation, No. 21.

${ }^{25}$ Law Reform (Divorce and Marriage) Act 1976, s 10.

${ }^{26}$ Islamic Family Law (Federal Territories) Act 1984, s 8.

${ }^{27}$ Azidah Abdul Kadir, Rusli Nordin, Shaiful Bahari Ismail, Mohd Jamil Yaacob, Wan Mustapha, and Wan Mohd Rushidi, "Validation of the Malay Version of Edinburgh Postnatal Depression Scale for Postnatal Women in Kelantan, Malaysia." Asia Pacific Family Medicine 3 (2004). 
the multiple needs for support includes shelter homes for pregnant mothers, adoption centres, child care services, transportation services, financial incentives as well as emotional and esteem support. ${ }^{28}$ Therefore, in managing the needs of pregnant teenagers, the Malaysian government endorses partnerships and cooperations from all parties and agencies, internationally and nationally involving the government departments and non-government organisations (NGOs). This is to ensure active engagement of all concerned in delivering effective outcomes through a holistic manner so that the teenagers achieve better fulfilment in their adult life. ${ }^{29}$

Nevertheless, there are still on-the-ground issues concerning teenage pregnancies that need to be addressed accordingly. The purpose of this study is to examine the adequacy of the current support systems within the capacities of the government, non-government organisations (NGOs) and social activists in protecting the welfare of pregnant teenagers in Malaysia. The result of the data indirectly illustrates the quality of the implementation of the laws and policies as well as the adequacies of the existing interventions in addressing the issues related to teenage pregnancies in Malaysia. The implementation measures set up in this study covers situations up until March 2018.

\section{METHODOLOGY}

This study combines both doctrinal and non-doctrinal research methods which utilises a mixed methodology of library research and fieldwork. The issues are identified from various articles, journals and reports via library research addressing concerns for teenage pregnancies which constitutes the primary reference. For the fieldwork, the study collected data from interviews with the relevant authorities from the Social Welfare Department (JKM), National Population and Family Planning Development Board (LPPKN), Ministry of Health (MOH), Attorney

\footnotetext{
${ }^{28}$ Norhasmah Mohd Zain, "Outcomes of Pregnancy among Unmarried Mothers in Malaysia," (PhD thesis, Universiti of Malaya, 2016).

${ }^{29}$ Nor Jana Saim, "Social Support, Coping, Resilience and Mental Health in Malaysian Unwed Young Pregnant Women and Young Mothers: Their Experiences While Living in a Shelter Home," (Ph.D. thesis, Umea University, Sweden, 2013).
} 
General's Chambers (AGC), Shariah Judiciary Department of Malaysia (JKSM), Department of Islamic Development Malaysia (JAKIM) and the enforcement agents like the administrators of the rehabilitation centres administered by the government (Taman Seri Puteri), the Selangor State government (Baitul Ehsan) and the non-government organisation (Raudhatus Sakinah) also a social activist, Syed Azmi Al-Habshi. Openended questions were used in order to allow the informants to further describe the problems encountered, the efforts and contribution done by them in their own words. However, some data are obtained from documentaries and news from YouTube, newspapers and reports due to the difficulty in accessing the representative of the Ministry of Education (MOE) and the Royal Police Malaysia (PDRM). The result of these interviews constitutes as supporting data to the primary reference.

\section{FINDINGS}

\section{Education}

This part of the article discusses the problems faced by teenagers who are pregnant. The discussion includes the current policies adopted by the government and existing laws and regulations that relate to this issue.

Pregnancy among teenagers is a significant cause of school dropout in Malaysia. ${ }^{30}$ A local study found that in 2016, 73.0\% of pregnant teenagers were no longer in school. ${ }^{31}$ A finding from another study indicated that $62.7 \%$ of them encountered study difficulties during pregnancy, $40.7 \%$ had to delay their studies, $17.3 \%$ stopped studying and $4.3 \%$ had to change to another school. ${ }^{32}$ This reflects the attitude of teenagers when dealing with out of wedlock pregnancy, where they

${ }^{30}$ S M Shahidul and A H M Zehadul Karim, "Factors Contributing to School Dropout among the Girls: A Review of Literature," European Journal of Research and Reflection in Educational Sciences 3, no. 2 (2015).

${ }^{31}$ Raten Manual Statistik Remaja Hamil JKN 2016 in Nik Rubiah Nik Abdul Rashid, "Motherhood in Childhood: Teenage Pregnancy \& MOH Initiatives" (paper presented at $13^{\text {th }}$ National Symposium on Adolescent Health NCD in Teens: Challenges and Opportunity, Kota Bharu, April 5-7, 2017).

${ }^{32}$ Norhasmah Mohd Zain, "Outcomes of Pregnancy among Unmarried Mothers in Malaysia," ( $\mathrm{PhD}$ thesis, Universiti of Malaya, 2016). 
would prefer to delay or stop studying at all, ${ }^{33}$ causing them to abandon their dreams, visions and inspirations. ${ }^{34}$

According to the Minister of Education, ${ }^{35}$ the education system in Malaysia does not bar pregnant students from attending schools. Instead, they are not allowed to be absent from school for a minimum of thirty consecutive days or sixty days in a year, otherwise, they will automatically be expelled. ${ }^{36}$ While this policy does not directly discourage pregnant students to continue to go to school, nevertheless it appears that not many efforts are done to actively encourage them either. This active encouragement includes providing for their special needs rather than the conventional classes such as a flexible timetable, comfortable uniforms, providing counsellors for emotional support and a place for childcare for the children after labour.

The Ministry of Women, Family and Community Development (MWFCD) is not in favour of setting-up a school separated from the formal school system because it will further put stigma to pregnant teenagers. MWFCD suggested pregnant teenagers should be absorbed in the normal school system and be allowed to defer their studies or make arrangements for them to re-enter in a new school after they have delivered. ${ }^{37}$ These recommendations are to ensure that teenagers do not lose the opportunity to continue their education despite being pregnant.

${ }^{33}$ Kul Bhushan Suri, "The Problem of Teenage Pregnancy: An Educational Imperative," Journal of Multicultural Social Work 3, no. 3 (1994).

${ }^{34}$ Rohany Nasir, Zainah Ahmad Zamani, Rozainee Khairudin, Wan Shahrazah Wan Sulaiman, Mohd Norahim Mohd Sani and Aizan Sofia Amin, "Depression, Loneliness and Cognitive Distortion among Young Unwed Pregnant Women in Malaysia: Counseling Implications", Asian Social Science 12, no. 8 (2016): 104-109.

${ }^{35}$ Debra Chong, “Don't Debate If You Haven't Read This: Pregnant Teens Can Go To School," The Malaysian Insider, September 20, 2010, accessed February 4, 2017, https://thedebatingnews.wordpress.com/2010/09/20/dont-debate-if-youhavent-read-this-pregnant-teens-can-go-to-school.

${ }^{36}$ Sekolah Menengah Kebangsaan Seri Sepang, Bandar Baru Salak Tinggi, Buku Peraturan Sekolah, Kesalahan Berat, Peraturan 7, Jadual 3.

37 UNICEF Malaysia, "Special School for Pregnant Teenagers," UNICEF Malaysia Official Website, July 27, 2010, accessed February 2, 2017, https://www.unicef.org/malaysia/media_news10-special-school-for-pregnantmothers.html. 
The government had initiated school programs through the Department of Welfare Malaysia (JKM) to ensure that pregnant teenagers do not lose the opportunity to continue their education in a school known as Taman Seri Puteri. In this institution, JKM offers various types of education and vocational programs designed to assist the teenagers in coping and completing their education, providing them with the necessary skills for future career and giving them basic guidance in understanding the religion and having good values. JKM also works in partnership with other government agencies, NGOs and external volunteers such as GIATMARA, Institut Latihan Perindustrian and Community Colleges in organising programs that can benefit the teenagers as well as providing them with the proper facilities and welltrained teachers to teach them the vocational training skills that might help them to reintegrate into the society. ${ }^{38}$ Although Taman Seri Puteri is a good initiative by the government, however, this institution is very limited. With a total of four rehabilitation centres in Malaysia, ${ }^{39}$ many pregnant teenagers would resort to other rehabilitation institutions run by the NGOs, where some have restricted facilities to support the teenagers to continue their education.

The Selangor State government has even taken extra measure to establish Baitul Ehsan under the Selangor Islamic Religious Council $(\text { MAIS })^{40}$ with the objective to provide services for rehabilitation, shelters, counselling and vocational skills to pregnant teenagers with social problems defined under the Shariah Criminal Offences Enactment Selangor 1995. ${ }^{41}$ Similar to Taman Seri Puteri, Baitul Ehsan provides the teenagers with the chance to complete their formal education, assisting them with tuition classes as well as preparing them for examination such

${ }^{38}$ Ministry of Women, Family and Community Development, "Taman Seri Puteri," Department of Social Welfare Official Website, accessed April 14, 2017 , http://www.jkm.gov.my/jkm/index.php?r=portal/left\&id=dS9TbzMvUDFmazl0 aXVLOGpoRTVzQT09.

${ }^{39}$ Rafidah Abdul Aziz (Social Welfare Department), Interviewed by Aishah Mohd Nor, Putrajaya, February 15, 2018.

${ }^{40}$ Shariah Criminal Offences Enactment Selangor 1995, s.53 and s.54.

${ }^{41}$ Shariah Criminal Offences Enactment Selangor 1995, Part IV. 
as PMR, SPM and STPM. ${ }^{42}$ The rehabilitation centre has reported success, according to a survey, where $70.0 \%$ of the girls showed selfimprovement presumably due to the effective approach. ${ }^{43}$ However, the admission of teenagers through the Shariah Court order is unpopular. Therefore, despite the abundance of resources by MAIS, Baitul Ehsan is underutilised where half of its capacity is vacant. Furthermore, the time of stay at the centre is a maximum of 6 months only. ${ }^{44}$ The concern is in the grasp of knowledge imparted to the girls given the short span of time in the centre.

Raudhatus Sakinah is another rehabilitation centre run by an NGO. The module used in Raudhatus Sakinah is more of a religious approach by giving pregnant teenagers Islamic guidance through classes and counselling sessions. Formal education is not the main focus of Raudhatus Sakinah. Hence, there are no academic classes during the stay. $^{45}$

In an interview with Syed Azmi Alhabshi, a social activist on children's welfare it was found that most of the teenagers dropped out of school before becoming pregnant. The majority of the teenagers were already not interested to go to school, and they are more inclined to work and earn a living. He suggested alternative skill-based programs like make-up skills, cooking and sewing to help them survive and reintegrate back in the society. ${ }^{46}$

The next part of this article continues to highlight how the Penal Code applies to certain acts done by these teenagers, especially acts of juvenile delinquency and other matters that may be considered as crimes.

${ }^{42}$ Majlis Agama Islam Selangor (MAIS), Manual Pelaksanaan Utama Modul Transformasi Ehsan (MTE), (Selangor: MAIS, 2015).

${ }^{43}$ Mohd Makhi Adnan (Baitul Ehsan), Interviewed by Aishah Mohd Nor, Selangor, February 19, 2018.

${ }^{44}$ Shariah Criminal Offences Enactment Selangor 1995, s 54(2).

${ }^{45}$ Muha Anun Mohd Noor known as Nurin (Raudhatus Sakinah), Interviewed by Aishah Mohd Nor, Selangor, January 11, 2018.

${ }^{46}$ Syed Azmi Alhabshi (social activist), Interviewed by Aishah Mohd Nor, Selangor, March 13, 2018. 


\section{The Penal Code}

The Penal Code is an Act relating to criminal offences in Malaysia. Under this Act, a child under the age of ten will not be criminally responsible for their actions. ${ }^{47}$ Meanwhile, for a child above ten and less than twelve years, his or her actions will depend on the child's state of maturity to understand and judge the nature and consequences of the conduct. This is known as the doli incapax provision. Where the Court for Children is in doubt as to the age of the child, an opinion should be sought from a medical officer. ${ }^{48}$

Children under the age of 18 years old are protected under the Child Act $2001,{ }^{49}$ which was enacted to fulfil Malaysia's obligations under UNCRC. Thus, any offences, committed by a 'child' as defined by the Child Act 2001, ${ }^{50}$ must be read together with the Penal Code. ${ }^{51}$ This study focuses on several types of offences relevant to pregnant teenagers.

\section{Abortion}

Abortion is an offence punishable under the Malaysian criminal law. ${ }^{52}$ However, there is an exception to legitimise the act of abortion, i.e., if the pregnancy endangers the life of the mother ${ }^{53}$ including the physical and mental health of the mother. ${ }^{54}$ It is also mentioned in the Code of Medical Ethics ${ }^{55}$ that the termination of pregnancy would not be an offence if a medical practitioner registered under the Medical Act $1971^{56}$ undertakes the procedure and such practitioner is in good faith that continuation of

\footnotetext{
${ }^{47}$ Penal Code, s 82.

${ }^{48}$ Penal Code, s 83.

${ }^{49}$ Child Act 2001.

${ }^{50}$ Child Act 2001, s. 17.

${ }^{51}$ Ministry of Women, Family and Community Development (MWFCD) and UNICEF Malaysia, The Malaysian Juvenile Justice System A Study of Mechanisms for Handling Children in Conflict with the Law, (Malaysia: MWFCD and UNICEF Malaysia, 2013).

${ }^{52}$ Penal Code, s 312-314.

${ }^{53}$ Penal Code, s 91.

${ }^{54}$ Penal Code, s 312.

${ }^{55}$ Medical Act 1971, s 15.

${ }^{56}$ Medical Act 1971, s 15.
} 
the pregnancy jeopardises the mental and physical health of the pregnant woman, exposing her life to a greater risk. ${ }^{57}$

The issue of abortion is rarely discussed openly in Malaysia. Therefore, not many are aware of the exceptions in the law that makes abortion legal. The profound perception that abortion is illegal makes them avoid seeking services in the public health sector and alternately opt for private services, which can be very expensive and dangerous. However, in desperation, some women would prefer to pay whatever it costs to perform an abortion. ${ }^{58}$

The government is aware of its Millennium Development Goals, which includes reducing the maternal death rates via access to safe abortion. ${ }^{59}$ In 2012, the first national guidelines on Termination of Pregnancy (TOP) was developed by the Ministry of Health (MOH) and circulated in government hospitals. ${ }^{60}$ The guidelines aim to bring attention to the complexities of the issues regarding induced abortion and the existing provisions for termination of pregnancy in terms of professional ethics, legislation, religion, and reproductive rights among health care professionals when providing clinical care for women undergoing abortions. The $\mathrm{MOH}$ had revised the TOP guideline and suggested a component of mental assessment to determine the necessity for abortion. This new guideline is anticipated to be the first to apply a specific screening test for mental fitness where healthcare practitioners can recommend for an abortion if a standard mental illness is proven to

\footnotetext{
${ }^{57}$ Mazbah Termizi, Noor Ismawati Mohd Jaafar, Nurhidayah Abdullah, Mariam Saidona Tagaranao and Yasmin Hanani Mohd Safian, "Comparative Study on Punishment and Preventive Methods of Baby Dumping: Malaysian Perspectives", International Journal of Technical Research and Application 2, no. 4 (2014).

${ }^{58}$ Wah Yun Low, Wen Ting Tong, Yut Lin Wong, Ravindran Jegasothy and Sim Poey Choong, "Access to Safe Legal Abortion in Malaysia: Women's Insights and Health Sector Response", Asia-Pacific Journal of Public Health / Asia-Pacific Academic Consortium for Public Health 27, no. 1 (2015).

${ }^{59}$ Wah Yun Low, Wen Ting Tong, Yut Lin Wong, Ravindran Jegasothy, Sim Poey Choong, “Access to Safe Legal Abortion in Malaysia: Women's Insights and Health Sector Response," Asia-Pacific Journal of Public Health 27, no. 1 (2015).

${ }^{60}$ Ministry of Health Malaysia, "Guidelines on Termination of Pregnancy for Hospitals in the Ministry of Health," (Ministry of Health Malaysia, 2015).
} 
distress the mother due to her pregnancy. Nevertheless, at the time of writing, this new guideline is yet to be released and implemented. ${ }^{61}$

The national fatwa on abortion ${ }^{62}$ seems to be aligned with the Penal Code. ${ }^{63}$ With the revised TOP guideline, it triggers the question whether the Fatwa Councils should follow the footsteps of $\mathrm{MOH}$ to revisit the fatwa on abortion and redefine the meaning or assessment of mental health accordingly. However, when asked about this to the activist onthe-ground, he agrees to remain the status quo as a concern that a lenient fatwa creates an easy passage for the public to misinterpret the fatwa and take them into their own hands and subsequently, will open the floodgate to illegal and harmful abortion. ${ }^{64}$

\section{Infanticide}

Infanticide is terminating the life of a baby who is less than 12 months. Infanticide is normally done in the form of baby dumping or abandonment causing the death of a baby and it is an offence under the law. ${ }^{65}$ In Malaysia, from 2005 until January 2011, there were 517 baby dumping cases reported. Of the total, 203 were found alive while 287 were found dead. ${ }^{66}$ The statistics may not be accurate and are seen

${ }^{61}$ Dr Nik Rubiah Nik Abdul Rashid, Dr Majdah Mohamed and Matron Alejah Ali (Ministry of Health Malaysia), Interviewed by Aishah Mohd Nor, Putrajaya, February 8, 2018.

${ }^{62}$ The national fatwa allows for abortion to be carried out for a foetus less than 120 days of gestation if the mother's life is under threat or if the foetus is abnormal in Makiah Tussaripah Jamil, Abdul Mukti Baharudin and Hisam Satari, "Pengguguran Bayi Menurut Perspektif Islam dan Perundangan di Malaysia", Global Journal Al-Thaqafah. Vol.2, Issue 1(2012).

${ }^{63}$ s 312-314.

${ }^{64}$ Syed Azmi Alhabshi (social activist), Interviewed by Aishah Mohd Nor, Selangor, March 13, 2018.

${ }^{65}$ Penal Code, s 309A.

${ }^{66}$ Nazni Noordin, Zaherawati Zakaria, Mohd Zool Hilmie Mohamed Sawal, Zaliha $\mathrm{Hj}$. Hussin, Kamarudin Ngah and Jennifah Nordin, "The Voice of Youngsters on Baby Dumping Issues in Malaysia," International Journal of Trade, Economics and Finance 3, no. 1 (2012). 
smaller in numbers as compared to the actual rate. Some abandoned cases are not found at all by the authorities. ${ }^{67}$

Initially, infanticide was made an offence under the law to curb the problem of baby dumping by sentencing the person responsible for causing the death of the baby. Research has proven that the method of sentencing works and it has managed to reduce cases related to baby dumping in Malaysia. ${ }^{68}$ Nevertheless, penalising the teenagers for infanticide seems to contradict the international standards calling for increased protection for children. Being young and vulnerable, with lack of support and afraid of being stigmatised by the society, the capacity for sound decision making of these teenagers may have been impaired leading them to commit infanticide. ${ }^{69}$ Instead of punishing them, some are of the opinion that the laws and authorities should assist the teenage mothers in handling the scenario subtly through preventive methods such as creating awareness at all levels in school and in the society, encouraging monitoring actions from the parents, teachers and friends by strengthening the support system for the teenagers and providing nonjudgemental and constructive advice to the teenagers in dealing with the unwanted child. $^{70}$

A baby hatch program was launched in Selangor by the OrphanCare Foundation. This program was a good initiative as it managed to save abandoned babies, helped adoption, gave hope to prospective families, as

${ }^{67}$ S.K. Thanusha Devi, "Born to Be Abandoned and Left to Chance," Malay Mail, November 2, 2015, accessed July 22, 2018, https://www.malaymail.com/s/997611/born-to-be-abandoned-and-left-to-chance. ${ }^{68}$ Mazbah Termizi, Noor Ismawati Mohd Jaafar, Nurhidayah Abdullah, Mariam Saidona Tagaranao and Yasmin Hanani Mohd Safian, "Comparative Study on Punishment and Preventive Methods of Baby Dumping: Malaysian Perspectives," International Journal of Technical Research and Application 2, no. 4 (2014).

${ }^{69}$ UNICEF East Asia and Pacific Regional Office (EAPRO), Legal Protection From Violence: Analysis of Domestic Laws Related to Violence Against Children in ASEAN Member States, (Bangkok: EAPRO, 2015).

${ }^{70}$ Mazbah Termizi, Noor Ismawati Mohd Jaafar, Nurhidayah Abdullah, Mariam Saidona Tagaranao and Yasmin Hanani Mohd Safian, "Comparative Study on Punishment and Preventive Methods of Baby Dumping: Malaysian Perspectives," International Journal of Technical Research and Application 2, no. 4 (2014). 
well as help to counsel the biological mothers resulting them to eventually love and care for the babies as the guardian themselves. Despite the negative reactions from the conservative society, it has been reported that the baby hatch centre had helped to reduce the numbers of baby dumping in Malaysia. ${ }^{71}$ However, to-date, there are only 13 baby hatches concentrated in certain city areas throughout Malaysia. ${ }^{72}$ It has yet to be made a project locally accessible in all states including in the remote areas. Furthermore, many are still unaware of this effort due to its limited promotion. ${ }^{73}$

\section{Sexual Offences Against Children}

In Malaysia, the statistics between 2000 and 2015 revealed that out of 37,263 rape cases, half of it was committed against children between the age of 13 and 15 (16,265 cases). ${ }^{74}$ Out of the total cases, some 2,854 were sodomised and 4,739 were incest-raped. ${ }^{75}$ Statistics from the Royal Police Malaysia recorded that from 2015 to 2017, the biological father holds the highest predator for the crime of incest (25.5\%), while

${ }^{71}$ Mazbah Termizi, Noor Ismawati Mohd Jaafar, Nurhidayah Abdullah, Mariam Saidona Tagaranao and Yasmin Hanani Mohd Safian, "Comparative Study on Punishment and Preventive Methods of Baby Dumping: Malaysian Perspectives," International Journal of Technical Research and Application 2, no. 4 (2014).

72 OrphanCare Foundation, "Baby Hatch Centres," accessed July 5, 2018, http://orphancare.org.my/our-work/community-services/baby-hatch/baby-hatchcentres/.

${ }^{73}$ Syed Azmi Alhabshi (social activist), Interviewed by Aishah Mohd Nor, Selangor, March 13, 2018.

${ }^{74}$ Ivanpal Singh Grewal, "We Need to Get Serious about Sexual Crimes," The Star Online, February 9, 2017, accessed July 9, 2018, https://www.thestar.com.my/opinion/online-exclusive/makingprogress/2017/02/09/we-need-to-get-serious-about-sexual-crimes/.

${ }^{75}$ Ivanpal Singh Grewal, "We Need to Get Serious about Sexual Crimes," The Star Online, February 9, 2017, accessed July 9, 2018, https://www.thestar.com.my/opinion/online-exclusive/makingprogress/2017/02/09/we-need-to-get-serious-about-sexual-crimes/. 
stepfather holds second highest predator $(25.2 \%)$ and the third is uncles or male relative $(17.4 \%){ }^{76}$

The statistics indicate that children in Malaysia are exposed to sexual crimes within the society. In light of the above, the Sexual Offences Against Children Act 2017 was passed by the parliament on 4 April 2017 and enforced on 10 July 2017. The Act aims to protect children under the age of 18 years old against any sexual offences. ${ }^{77}$ Since this Act is newly enacted, many sections have yet to be challenged in court to define the meaning of sexual offences. At the time of writing, there are many cases still in trial and those convicted are perpetrators who pleaded guilty in court. ${ }^{78}$ However, the new law introduces a specific section on child grooming, making it an offence to sexually communicate, meet a child for sexual purposes or be involved in any physical sexual assault besides imposing a duty to the public, not just the parents, to make a report about sexual cases involving children. Under the new law, those who abuse their positions of trust where children are placed under their care including supervisors and health care service providers or those withholding information, will be punished. This Act also introduces more severe punishments to the perpetrators compared to any other Acts in Malaysia $^{79}$ such as punishing any male offender above 50 years old with whipping. ${ }^{80}$

76 "Kempen \#stopperogoldalamrumah Dekati Masyarakat," Free Malaysia Today, February 19, 2018, accessed March 28, 2018, http://www.freemalaysiatoday.com/category/bahasa/2018/02/19/kempen-halangsumbang-mahram-dekati- masyarakat/.

${ }^{77}$ Akil Yunus and Martin Carvalho, "Laws on Sexual Offences against Children Tabled", The Star, 28 March, 2017, http://www.thestar.com.my/news/nation/2017/03/28/sexual-offences-bill-tabled (accessed 2 May, 2017).

${ }^{78}$ Aimi Syazwani Sarmin and Nordalina Ali (Attorney General's Chambers), Interviewed by Aishah Mohd Nor, Putrajaya, March 10, 2018.

${ }^{79}$ Aimi Syazwani Sarmin and Nordalina Ali (Attorney General's Chambers), Interviewed by Aishah Mohd Nor, Putrajaya, March 10, 2018.

${ }^{80}$ Nik Imran Abdullah, Arfa Yunus and Hana Naz Harun, "Parliament Passes Landmark Sexual Offences against Children Bill", New Straits Times, 4 April, 2017, http://www.nst.com.my/news/2017/04/227214/parliament-passeslandmark-sexual-offences-against-children-bill (accessed 2 May, 2017). 
A Special Court for children was also set up under this Act and was launched on 22 June 2017 to strengthen the law and protect children against sexual perpetrators. ${ }^{81}$ Cases charged are brought to the Special Child Court where the Judges are experts in child cases. Nevertheless, since the implementation is still new, there is currently only one Special Child Court in Malaysia located in Putrajaya, hearing cases from Kuala Lumpur and Selangor. More Special Child Courts are anticipated to be established gradually in other states of Malaysia. ${ }^{82}$

\section{Child Marriage}

In 2010, the United Nation reported over 82,000 married women in Malaysia, were girls between the ages of 15 and 19 years old. For the same year, MWFCD revealed nearly 15,000 girls below the age of 15 years old were in marriage. ${ }^{83}$ Researchers also found 5,215 cases $^{84}$ of married non-Muslim female children (16 to 18 years old) from 2005 to October 2015. As for Muslims, the Department of Shariah Judiciary Malaysia recorded 6,537 cases of marriage among Muslim children from 2012 to March 2018. ${ }^{85}$

${ }^{81}$ Aedi Asri, "Special Court for Child Sexual Crimes Launched," Free Malaysia Today, June 22, 2017, accessed October 31, 2017, http://www.freemalaysiatoday.com/category/nation/2017/06/22/special-courtfor-child-sexual-crimes-launched.

${ }^{82}$ Aimi Syazwani Sarmin and Nordalina Ali (Attorney General's Chambers), Interviewed by Aishah Mohd Nor, Putrajaya, March 10, 2018.

${ }^{83}$ Voice of the Children, "Child Marriage in Malaysia, a Child Rights Issue," Website Girls Not Brides, May 24, 2013, accessed November 1, 2017, https://www.girlsnotbrides.org/tackling-child-marriage-in-malaysia-a-childrights-activists-perspective/.

84 "Department of Statistics Malaysia Official Portal," accessed October 18, 2017 ,

https://www.statistics.gov.my/index.php?r=column/ctheme\&menu_id=L0pheU4 3NWJwRWVSZklWdzQ4TlhUUT09\&bul_id=MDMxdHZjWTk1SjFzTzNkRX YzcVZjdz09.

${ }^{85}$ Mohd Na'im Mokhtar (Shariah Court of Appeal Judge), Interviewed by Aishah Mohd Nor, Putrajaya, March 15, 2018. 
Family matters for non-Muslims in Malaysia are governed under the Law Reform (Marriage and Divorce) Act 1976 (LRA 1976). ${ }^{86}$ Under LRA 1976, child marriages for girls are not allowed if she is below 16 years old. However, if she is between 16 to 18 years old, she is allowed to marry with the consent of the Chief Minister and if she is between 18 to 21 years old, the parents must consent to the marriage. Only at the age of 21 years old and above, can she have her own prerogative consent. ${ }^{87}$ Under this Act, both parties must willingly consent to the marriage. Otherwise, it is an offence to force or threaten someone to compel him or her to marry against his or her will. ${ }^{88}$ The Penal Code also criminalises forced marriage of a woman where it is affected through kidnapping and abduction. ${ }^{89}$ Forced marriages are unacceptable and a serious breach of an individual's rights, including the child's right. ${ }^{90}$

Muslims in Malaysia are generally governed under the Islamic law in matters relating to personal or family matters. Under the Islamic Family Law (Federal Territories) Act $1984,{ }^{91}$ the minimum age for marriage is 16 years old for a girl. Nonetheless, it gives exceptions to marry below the age of 16 years old with permission from the Shariah judge. There are many reasons to consent to the marriage but generally these are based on the grounds of religion, ethnicity or custom, physical signs of puberty, parental consent, pregnancy or other reasons related to the personal circumstances of children, couples and families. ${ }^{92}$

The primary issue of concern is the best interest of the child principle enshrined in United Nations Convention on the Rights of the Child. When a teenager becomes pregnant, for many reasons including rape or incest, many parents would force or convince the teenager into marriage to hide the pregnancy in fear of shame and disgrace. The

\footnotetext{
${ }^{86}$ Law Reform (Marriage and Divorce) Act 1976, s 3.

${ }^{87}$ Law Reform (Marriage and Divorce) Act 1976, s 10.

${ }^{88}$ Law Reform (Marriage and Divorce) Act 1976, s 37.

${ }^{89}$ Penal Code, s 366.
}

${ }^{90}$ UNICEF East Asia and Pacific Regional Office (EAPRO), Legal Protection From Violence: Analysis of Domestic Laws Related to Violence Against Children in ASEAN Member States, (Bangkok: EAPRO, 2015).

${ }^{91}$ Islamic Family Law (Federal Territories) Act 1984, s 8.

92 Noor Aziah Mohd Awal and Mohd Al Adib Samuri, Child Marriages in Malaysia, Working Paper for UNICEF Malaysia, (Malaysia: UNICEF Malaysia, 2018). 
marriage is unlikely for the best interest of the child, but rather to safeguard the parents and/or the child from humiliation and social stigma. It is submitted that child marriages against the best interest of the child will open doors to more harm than good, especially if she is forced to marry the abuser himself. ${ }^{93}$

Although forced marriage is a crime under the non-Muslim family law, ${ }^{94}$ however, the perpetrators of forced marriage are usually the parents or close family members of the teenager. The teenager will have to agree to the marriage as they are emotionally and psychologically pressured to consent, due to their age, maturity and full reliance on the family. And yet, even if they knew of their rights and are fully aware of the consequences, they will still be reluctant to come forward afraid that the parents will be prosecuted and face criminal sanctions. ${ }^{95}$ Whilst the Islamic family law does not provide punishment for forced marriage, nevertheless, the parties are still subject to the Penal Code criminalising forced marriage of a woman through kidnapping and abduction. ${ }^{96}$

The next part of the article concentrates on the issue of the lack of support systems in Malaysia. It looks into the types of support systems needed in order to curb the problems related to teenage pregnancies.

\section{Lacking Support Systems}

\section{Parental and Family Support}

Parental care and guidance are essential to teenagers. Studies indicate that parents who are more involved with their children and respond positively by giving emotional and mental encouragement, stimulation and guidance, is shown to possess a good level of mental health among

\footnotetext{
${ }^{93}$ UNICEF East Asia and Pacific Regional Office (EAPRO), Legal Protection From Violence: Analysis of Domestic Laws Related to Violence Against Children in ASEAN Member States, (Bangkok: EAPRO, 2015).

${ }^{94}$ Law Reform (Marriage and Divorce) Act 1976, s 37; Penal Code, s 366.

${ }^{95}$ UNICEF East Asia and Pacific Regional Office (EAPRO), Legal Protection From Violence: Analysis of Domestic Laws Related to Violence Against Children in ASEAN Member States, (Bangkok: EAPRO, 2015).

${ }^{96}$ Penal Code, s 366.
} 
teenagers ${ }^{97}$ and help to hinder them from further committing wrongful acts in the future. ${ }^{98}$

Parental guidance and support have significant impacts to the teenager as both preventive and supportive measures. As a preventive precaution, it is imperative for parents to guide their children in understanding sexual knowledge before they reach sexual maturation. This includes guiding them on matters pertaining to the physical changes of the body, their psychological needs and their general health. It has been found that strong parental guidance resulted in a lower rate of sexual initiation, hence, a reduction in pregnancy rates. ${ }^{99}$

Supportive measures are just as important as the above especially after discovering the pregnancy and preparing for motherhood. The teenagers must be properly guided with the adequate knowledge of what to expect during pregnancy and motherhood as well as equipping them with parenting skills and knowledge which includes nutrition, healthcare, financial awareness and future possibilities to help teenage mothers become good parents. Since good parenting skills start from home, parents should primarily be responsible to monitor and be a good mentor to the teenage mothers by providing parenting home training and close childcare assistance. This parenting mentoring can bring the motherdaughter bonding closer and can be a preventive way to reduce the criminal offences of abortion and infanticide. For long-term periods, it can help to reduce the stigma in the society, stop the blaming circle and focus on the betterment of the mother and the baby in the future. ${ }^{100}$

${ }^{97}$ Nor Jana Bte Saim, "Social Support, Coping, Resilience and Mental Health in Malaysian Unwed Young Pregnant Women and Young Mothers: Their Experiences While Living in a Shelter Home," (PhD thesis, Umea University, Sweden, 2013).

${ }^{98}$ Zarina Ismail, Mohd Mahzan Awang and Abdul Razaq Ahmad, "Delinquent Students: Review from the Perspective of Family Environment," International Conference on Education and Regional Development (2016).

${ }^{99}$ Azmawaty Mohamad Nor, Shanina Sharatol, Ahmad Shah and Melati Sumari, "The Education of Pregnant Teenagers in Malaysia: An Overview," Malaysian Online Journal Of Counseling 3, no. 2 (2017).

${ }^{100}$ Norhasmah Mohd Zain, "Outcomes of Pregnancy among Unmarried Mothers in Malaysia," (PhD thesis, Universiti of Malaya, 2016). 
Recognising the importance of the family unit for ensuring the wellbeing of children, a number of initiatives were introduced by the government, for example, the launching of National Family Policy in 2011 and 1Malaysia Family First movement in 2012. ${ }^{101}$ The LPPKN as a leading agency in the development of quality family institution manages a number of programs such as 'Smart Start' for pre-marital couples, 'Family Life-Cycle Program' focusing on techniques for parenting teenagers and Kasih Module Package (e-Kasih package) to strengthen the family institution which consists of several packages including module on Parenting Teenagers (Mutiara Kasih), module of Teenage Development (Permata Kasih), involvement of father (Pancaran Kasih) and preparation for marriage (Bahtera Kasih). ${ }^{102}$

\section{Medical Support}

Teenage is a period of gradual transition from childhood to adulthood. Thus, the MOH had introduced the National Adolescent Health Plan 2006-2020 and a few guidelines on the management of teenager sexual reproductive health through several modules such as 'Engaging the Adolescent Module Using HEADSS Framework ${ }^{103}$ and Guidelines on Managing Sexual Reproductive Health Problems among Adolescents at Primary Care. Health promotion through social media, peer to peer programs, training among health practitioners and collaborating with other agencies are among other efforts of $\mathrm{MOH}$.

The One Stop Crisis Centre (OSCC) was established in all Emergency and Trauma Departments in government hospitals. The aim is to assist the victims of any forms of violence such as domestic violence, rape, sodomy and child abuse by providing prompt medical examination

101 Lembaga Penduduk Dan Pembangunan Keluarga Negara (LPPKN), "Assessment of the Status of Implementation of the ICPD-POA," accessed July 22, 2018, www.lppkn.gov.my.

${ }^{102}$ Lembaga Penduduk Dan Pembangunan Keluarga Negara (LPPKN), "Pakej Modul KASIH," accessed July 22, 2018, http://www.lppkn.gov.my/index.php/perkhidmatan-pembangunan-keluarga/168pk0003.html.

${ }^{103}$ HEADSS is an acronym for the topics that physicians need to cover i.e., home, education, activities/employment, drugs, suicidality and sex. 
and treatment, psychological support and counselling as well as referrals for shelter and legal aid. Managing the victims are challenging due to the various disciplines involved. Therefore, collaboration with other agencies helps to ensure the process and continuity of care to the victims is prompt and appropriate. ${ }^{104}$ OSCC is a good initiative from the government. However, it encounters cases for victims of sexual offences only. It does not include unwanted pregnancy as a result of a consensual act of the teenager.

\section{Social Support}

\section{Shelter Homes}

Shelter homes are one of the social interventions established to help teenagers coping with unwanted pregnancies and avoid abandonment of babies. According to research, ${ }^{105}$ the respondents found support and guidance in the shelter homes where they are given a second chance to start a new life. For some, this would be the main support during their pregnancy, particularly in getting regular antenatal care. The shelter homes are seen as a source of social support to the women and their families instead of a place for punishment or isolation, particularly the cases of sexual abuse and abandonment from the male partner. ${ }^{106}$ One local study revealed that $84.0 \%$ of unmarried women who were placed in the shelter homes experienced moderate to high level of psychological well-being due to social support provided by the shelter homes. ${ }^{107}$

104 Ministry of Health Malaysia, "One Stop Crisis Center: Policy and Guidelines for Hospitals," (Ministry of Health Malaysia, 2015).

${ }^{105}$ Nor Jana Saim, "Social Support, Coping, Resilience and Mental Health in Malaysian Unwed Young Pregnant Women and Young Mothers: Their Experiences While Living in a Shelter Home," (Ph.D. thesis, Umea University, Sweden, 2013).

${ }^{106}$ Nor Jana Saim, "Social Support, Coping, Resilience and Mental Health in Malaysian Unwed Young Pregnant Women and Young Mothers: Their Experiences While Living in a Shelter Home," (Ph.D. thesis, Umea University, Sweden, 2013).

107 Norshidah Nordin, Rohaya Abd Wahab, and Farhana Wan Yunus, "Psychological Well-Being of Young Unwed Pregnant Women: Implications for 
Nonetheless, most of the teenagers were initially reluctant to stay in the shelter homes having to endure the problems alone without their parents or partners. In the shelter homes, the teenagers felt separation anxiety and lack of family support due to the social limitation regulations where they are unable to see their parents or family regularly and have to be independent to do their own household work. ${ }^{108}$

In a discussion with a social activist, Syed Azmi Alhabshi, he pointed out that some teenagers were hesitant to stay in the shelter homes provided by the government or certain NGOs due to its strict regulations, such as not allowing handphones or television, having restriction in meeting others (family or partner), and being put in isolation (not allowed to come in and out from the shelter homes). They would prefer free timetable and stress-free environment of shelter homes instead of a fixed module for rehabilitation, like Rumah Kita. ${ }^{109}$

\section{Sexual Reproductive Health Education}

A 'Sexual Behaviour Among Adolescent' survey reported that $35.3 \%$ teenagers had exposure to pornography, $19.5 \%$ had masturbation, $4.8 \%$ had experienced sexual intercourse, $2.9 \%$ had phone sex, $1.7 \%$ had cyber-sex and $0.3 \%$ had a sex toy. ${ }^{110}$ A documentary on sex education in Malaysia revealed that from 3,000 teenage pregnancies registered, $75.0 \%$ of them did not know how to protect themselves from pregnancies. They were said to be victims of ignorance. ${ }^{111}$ This shows that the reluctance to

Extension Education and Programs," Procedia-Social and Behavioral Sciences 68 (2012).

${ }^{108}$ Nor Jana Saim, Mona Dufåker, Malin Erikson and Mehdi Ghazinour, "Listen to the Voices of Unwed Teenage Mothers in Malaysian Shelter Homes: An Explorative Study," Global Journal of Health Science 5, no. 5 (2013).

109 Syed Azmi Alhabshi (social activist), Interviewed by Aishah Mohd Nor, Selangor, March 13, 2018.

${ }^{110}$ National Population and Family Development Board, Malaysia, "Report on key findings Fifth Malaysian Population and Family survey (MPFS-5) 2014," 2016, 92, accessed July 22, 2018, http://familyrepository.lppkn.gov.my/id/eprint/659.

${ }^{111}$ R.AGE, "Let's (Not) Talk About Sex," YouTube Video, 09:07, June 2018, accessed June 25, 2018 https://www.youtube.com/watch?v=Y5NCk2XVjwQ. 
address teenagers' concern about sexuality leads to detrimental consequences.

The MOE had introduced the elements of Family Health Education (FHE) to primary school in physical and health education classes since 1994 and in secondary school since 1989. The aim is to enable students to obtain knowledge regarding the physical, emotional and social changes that they undergo. ${ }^{112}$ A review on the Malaysian school education found the syllabus for secondary school lacking as sex education was mainly focusing on moral values instead of discussing on a healthy relationship, establishing better decision making, imparting responsible behaviours and giving practical real-life advice. ${ }^{113}$

The challenges of implementing sex education in school are the readiness of the teachers to teach. In practice, teachers have shied away from teaching family health education as they are not skilled in dealing with what are deemed sensitive and personal issues. ${ }^{114}$ Some felt unwilling and involuntary to teach what they believe to be in contradiction to their religion, while others are unhappy being assigned to teach sex education when they are untrained in the subject area. These factors often lead to inattentive teachings and ineffective outcomes. ${ }^{115}$

Alternatively, MWFCD through LPPKN took the effort to introduce sex education for teenagers ${ }^{116}$ through educational materials, programs and services such as booklets entitled Rahsia Remaja, 3R, Demi Cinta, I'm in Control Modules, Cakna Diri and No Apologies. Following that, a

${ }^{112}$ Norhasmah Mohd Zain, "Outcomes of Pregnancy among Unmarried Mothers in Malaysia," (PhD thesis, Universiti of Malaya, 2016).

${ }^{113}$ Samantha Chow in R.AGE, "Let's (Not) Talk About Sex," YouTube Video, 09:07, June 2018, accessed June 25, 2018 https://www.youtube.com/watch?v=Y5NCk2XVjwQ.

${ }^{114}$ Lok Yim Pheng, Former Secretary General, National Union of the Teaching Profession in R.AGE, "Let's (Not) Talk About Sex," YouTube Video, 09:07, $\begin{array}{llll}\text { June 2018, accessed June } & 2018,\end{array}$ https://www.youtube.com/watch?v=Y5NCk2XVjwQ.

${ }^{115}$ Norhasmah Mohd Zain, "Outcomes of Pregnancy among Unmarried Mothers in Malaysia," (PhD thesis, Universiti of Malaya, 2016).

116 T.K Letchumy Tamboo, "Sex Education, Finally," Malaysia Today, October 6, 2011, accessed July 9, 2018, http://www.malaysia-today.net/2011/10/06/sexeducation-finally/. 
more comprehensive educational module on sex and reproductive health module called Pekerti has been introduced to be implemented at centres for teenagers such as kafe@Teen. ${ }^{117}$ However, these initiatives are not enough to address the issue of sexual ignorance among teenagers. Since the programs are voluntary, the concern is that those who sign onto the programs are not the targeted teenagers at risk, therefore, creating a wider gap to the social problems in the society.

\section{Youth Development Program/Centre}

As Malaysia undergoes rapid urbanisation, teenagers not only have to face challenges of growing up but also be prepared to face the multitude of challenges and stress from the environment. Realising this, the ministries, government agencies and NGOs are working together in creating effective youth development programs such as iM4U and Rakan Muda by the Ministry of Youth and Sports, ${ }^{118}$ Kafe@ Teen by LPPKN and other smart partnership programs among agencies. These youthbased programs enable the teenagers to voice out their opinion in helping to recognise their existence and worth, as well as, to level inequalities and overcome discrimination, especially for teenagers with disabilities or residing in remote areas. ${ }^{119}$ These initiatives provide safe space for the teenagers to develop their social skills and participate in giving ideas and volunteering for the community. However, continuous active participation is required to make sure that these programs are effective in the long-run. Hence, the result may vary from one place to another depending on the participation of the community in the area.

${ }^{117}$ Salmi Razali, Syed Ahmad Hassan Syed Almashoor, Aimi Nadia Yusoff and Husna Hassan Basri, "Newspaper Analysis on Filicide and Infant Abandonment in Malaysia," Journal of Media and Information Warfare 8 (2016).

${ }^{118}$ Phaik Lin Khoo, "Government Initiative in the Policy and Practice of Sport for All in Malaysia" (Ph.D. thesis, University of Malaya, 2002).

${ }^{119}$ Lembaga Penduduk Dan Pembangunan Keluarga Negara (LPPKN), "Pusat Remaja Kafe@Teen,” http://www.lppkn.gov.my/index.php/perkhidmatankesihatan-reproduktif/103-kafe-teen-1.html (accessed 22 July, 2018). 


\section{Access to Service}

The National Child Policy and the National Child Protection Policy was introduced in 2009 to encourage a systematic approach to advocacy and building an effective operational system to help children and propose interventions that would promote children's well-being. This was further elaborated through the strategy of primary prevention initiatives, secondary preventions or early intervention services and tertiary interventions. ${ }^{120}$ But most importantly, these services are expected to serve the clients objectively. This can only happen with client-friendly and responsive services that are made easily accessible to the public. Nonetheless, some services have tight bureaucracy and limited space like the shelter homes, which requires a court order and are subject to the vacancy of the homes when applying. ${ }^{121}$ For these desperate teenagers, to come out and seek help from others require a lot of effort and courage, hence, to be asked to wait and go through the lengthy procedures and sometimes, be turned down due to the tight bureaucracy, is not fair for them. A majority feels exposed and are afraid that certain sanctions will be imposed against them for seeking help. ${ }^{122}$ Furthermore, most services in Malaysia are not centralised. The teenagers would have to refer to various centres for different kinds of services, making it more difficult for them to access help from the authorised persons.

\section{Mass Media}

In Malaysia, the mass media such as television, radio, newspaper and magazines as well as the internet are the main sources of information. In the current society, where people are internet-savvy, information is mostly received from social media compared to other sources of information. Thus, the contents of the information in the media are crucial for the community to receive correct knowledge through these

\footnotetext{
${ }^{120}$ Ministry of Women, Family and Community Development (MWFCD) and UNICEF, "Child Protection and Welfare Services in Malaysia," (Beijing: MWFCD and UNICEF, 2010).

${ }^{121}$ Rafidah Abdul Aziz (Social Welfare Department), Interviewed by Aishah Mohd Nor, Putrajaya, February 15, 2018.

122 Syed Azmi Alhabshi (social activist), Interviewed by Aishah Mohd Nor, Selangor, March 13, 2018.
} 
effective channels. ${ }^{123}$ The media should actively participate in advocating teenager issues such as the importance of schooling, prevention from dropouts and child marriage. This can only happen with a good collaboration of the media. Furthermore, the mobilisation of social media such as awareness campaigns through Facebook, Twitter, Instagram and YouTube is just as important to effectively reach the society.

\section{DISCUSSIONS AND RECOMMENDATIONS}

The objective of the study is to evaluate the adequacy of the current support systems in addressing the issues of teenage pregnancies in Malaysia. With regards to the issue of education, it was found that majority of the teenagers were not interested to continue schooling and had dropped out of school before getting pregnant. Even for those who dropped out after becoming pregnant, they were more interested to work, earn a living and take care of their baby instead of completing school. The concentration on education should focus on providing relevant skills with accredited certification to open more job opportunities for the teenagers to have a better future ahead.

Rehabilitation centres with special schools administered or supervised by the government are no longer a first-choice solution for pregnant teenagers due to the strict rules and regulations. Despite the facilities, comprehensive modules and abundance of resources, some rehabilitation centres are underutilised. These teenagers would rather be in a stress-free environment where they are allowed to have access to the society through internet, family or partner visits with no curfew and enjoy their daily routine without having a fixed timetable. When the current rehabilitation centres are deemed to be too strict, the teenagers felt they are being disciplined in a house isolated from the society. Instead of giving them a second chance, it is perceived to be like a double punishment for them.

The issue of abortion should be more openly discussed in addition to creating awareness on safe and legal abortion. Safety also includes

${ }^{123}$ Mus Chairil Samani, Jamilah Maliki, Mohd Helmi Abd Rahim, Mat Pauzi Abd Rahman and Normah Mustaffa, "The Media Agenda of the New and Traditional Media in Malaysia: Constructing Realities," Special Issue 1 (2015). 
making sure that abortions will not be carried out by clandestine and unskilled providers who operate in situations that endanger women's lives, even if they have the best of intentions. With lack of information on abortion, a teenager has little or no recourse to safe abortion, even if she is seriously injured, badly treated, refused pain relief, sent home in a poor condition, charged a large amount of money or suffers any other form of negligence or malpractice. Continuing pregnancies following attempts at self-induced abortion are not uncommon and they may need follow-up care for other reasons, but it may be impossible especially when abortion is done secretly.

For crime-related issues like abortion and infanticide, punitive method is seen more popular in Malaysia. This type of approach can be ineffective, breeds resentment and makes situations worse as minors, especially teenagers, can be resentful of punishment rather than reflective on their actions. Whenever dealing with blunders, young people requires an opportunity to be heard, properly be advised and participate in making decisions, as well as being taught on handling responsibilities. Punishing the teenager does not teach them, instead, it will push them away from society out of fear and guilt. Moreover, punitive method seems to contradict the international standards calling for increased protection for children. ${ }^{124}$

Sexual offences against children have become an alarming issue in Malaysia. With the Sexual Offences Against Children Act 2017, it is anticipated that everyone, in a communal effort, will play a role in protecting children against sexual offences. Though the Act is still new, nevertheless, its existence fills in the lacuna of the current laws on the protection of children and provides wider alternatives for Deputy Public Prosecutors to seek justice for the child-victims. It is also about time for the Malaysian legal system to establish a Special Court for children to complement the other efforts from other ministries and agencies in protecting children.

In respect to child marriage, there have been efforts from the Muslim authorities to increase the age of marriage for Muslim girls to 18 years

${ }^{124}$ UNICEF East Asia and Pacific Regional Office (EAPRO), "Legal Protection From Violence: Analysis of Domestic Laws Related to Violence Against Children in ASEAN Member States," (Bangkok: EAPRO, 2015). 
old. A Standard of Procedure (SOP) on the application of Muslim child marriage in the Shariah Courts in Malaysia was presented to JKSM in Putrajaya. The SOP focuses on a comprehensive guideline in considering an application of child marriage in the Shariah Courts, from the tasks of the officers at the registration counter to the hearing of the case, the documents and witnesses to corroborate the application and the considerations of the Shariah Courts. ${ }^{125}$ However, this proposed guideline is still at an early stage. It has yet to be tabled and discussed in the Mesyuarat Ketua-Ketua Hakim Shari'e Negeri to become a binding document through Arahan Amalan (Practice Direction). ${ }^{126}$ Once it is made a Practice Direction, the Shariah Courts are expected to be equipped with the skills and knowledge necessary to handle such an application.

The interventions and support systems from the ministries, agencies and NGOs such as medical support, social support and shelter homes have been numerous. Nevertheless, the promotions are limited and hence, many are unaware of the services provided. Some of the services are concentrated in city areas and in certain states only making it difficult to access especially for those living in remote areas. The operational services are also restricted during the office hours and some are lengthy with tight bureaucracy. The late responses are also a major factor for many to give up in asking for help and would resort for self-help. Furthermore, some of the services are not integrated and only focuses on one specific delivery, whereas a centralised centre is anticipated to be more effective. The lack of a holistic approach of services and structured collaboration is a major barrier in reaching and benefiting the targeted group. With a proper collaboration, it can utilise the expertise and reduce the cost of operational services.

In essence, Malaysia is still lacking in terms of laws, policies and interventions on teenage pregnancies. Malaysian's policy on teenage pregnancy focuses on health issues only, whereas other concerns such as welfare and protection are under children policies, which may not be suitable for pregnant teenagers with different needs and attention of their

\footnotetext{
${ }^{125}$ Noor Aziah Mohd Awal, "Child Marriage in Malaysia," (paper presented at Jabatan Kehakiman Syariah Malaysia (JKSM), August 5, 2017).

${ }^{126}$ Mohd Na'im Mokhtar (Shariah Judiciary Department Malaysia), Interviewed by Aishah Mohd Nor, Putrajaya, 15 March 2018.
} 
own. Though some interventions exist, however, they are lacking, outdated, less accessible and oblivious. The approaches and interventions are not people-centric. Instead, it serves more of program-oriented delivery in one-off seminars or awareness campaigns as preventive measures. Supportive interventions seem to be more controversial as it is seen to condone the illicit act that contradicts the cultural and religious aspects in Malaysia. While the preventive method is socially more accepted, nevertheless supportive method is just as necessary to stop the cycle and avoid more harm to the teenagers in the future.

Therefore, it is recommended to pool together all knowledge and practices into a coherent framework to ensure active engagement of all concerned in delivering effective outcomes through a holistic manner. For that reason, a comprehensive legal framework is necessary to govern teenage pregnancies in Malaysia in protecting their welfare and ensuring that the teenagers achieve a better fulfilment in their adult life. With a proper legal framework, national policies and plan of actions are more focused and structured, from operational services involving more stakeholders from government and NGOs to best model programs investments and researches. The outcome can be seen in the long run. When the welfare of these teenagers is protected and served, brighter futures can be fulfilled for them.

\section{CONCLUSION}

This study reveals that the current support systems in Malaysia are still lacking in meeting the current needs of pregnant teenagers. While Malaysia has made significant progress in establishing and strengthening the rights of children, nonetheless, the existing rights of children are still very general. It does not focus on the rights of pregnant teenagers, who deserve special rights of their own.

It is suggested that a comprehensive legal framework for teenage pregnancies in Malaysia would cater to their special needs which includes welfare and support to a safe, healthy and conducive environment to grow as well as protection against all forms of abuse and neglect. This framework is anticipated to make the implementation of laws and policies more effective through integrated services and proper monitoring enforcement within the purview of a specific national policy 
and plan of actions that are more focused and structured to ensure the welfare of pregnant teenagers in Malaysia are well preserved. 